\title{
Facilitating regulatory approval of multipurpose prevention technologies for sexual and reproductive health
}

Martha Brady

Population Council

Follow this and additional works at: https://knowledgecommons.popcouncil.org/departments_sbsr-hiv

Part of the Health Policy Commons, Health Services Research Commons, Immune System Diseases Commons, International Public Health Commons, Medicine and Health Commons, Pharmacy Administration, Policy and Regulation Commons, Virus Diseases Commons, and the Women's Health Commons How does access to this work benefit you? Let us know!

\section{Recommended Citation}

Brady, Martha. 2011. "Facilitating regulatory approval of multipurpose prevention technologies for sexual and reproductive health," brief. New York: Population Council. 


\section{Facilitating Regulatory Approval of} Multipurpose Prevention Technologies for Sexual and Reproductive Health

\section{The Need}

Multipurpose prevention technologies (MPTs) that address women's sexual and reproductive health (SRH) needs - through preventing unintended pregnancies and/ or sexually transmitted infections (STIs), including HIVcould make a major contribution to global health. Unsafe sex is an enormous public health problem for women, leading to the second largest cause of illness and disability worldwide. It is also a major factor in female mortality, especially in low-resource settings. The consequences of unsafe sex are inextricably linked, resulting in an unmet need for products that provide simultaneous protection against unintended pregnancy and STIs, including HIV.

\section{The Challenge}

Multipurpose prevention technologies are a unique and specialized subset of what regulatory agencies refer to as combination products. They often do not fit into the discrete categories - drug, device, or biologic —used by regulators to assess products. As such, MPTs face an uncertain regulatory environment that can serve as a major disincentive to investment and an impediment to advancing candidate products.

\section{The Opportunity}

The current interest in scientific innovation provides an opportune moment to accelerate the development of combination products, including MPTs for SRH. Combination products represent cutting-edge science, employing new tools and techniques for product development. They also represent a promising area for health improvements and potentially greater user adherence. In some instances, combinations may lend themselves to more economical product development, lower costs, and potentially larger markets.

\section{The Response}

The US Agency for International Development (USAID) is injecting new energy into efforts to develop and deliver MPTs by supporting complementary programs to foster creativity and strategic thinking on product development, innovative approaches to trial designs to test new products, and regulatory pathways for product development and licensure. The Population Council is playing a central role in this effort by spearheading work to clarify and inform regulatory pathways for MPTs.

\section{Main Project Activities: Facilitating Regulatory Approval for MPTs}

- Review existing guidance and its application to MPTs for sexual and reproductive health

- Convene dialogue with key thought leaders and content area experts

- Foster strategic engagement with regulators and current/potential MPT product developers

- Develop an MPT regulatory road map

\section{GUIDING PRINCIPLES}

Focus on sexual and reproductive health

Solutions-oriented approach

Bridge reproductive health and HIV product development efforts

Glean insights from other products

Collaborate with and complement related initiatives 
Working with the World Health Organization and other key stakeholders, the Council will stimulate thinking and promote problem-solving around MPT regulatory pathways with the goal of influencing and shaping regulatory approval processes for MPTs, and developing a road map of possible regulatory pathways as a foundation for their approval. The Council will engage key regulatory authorities such as the US Food and Drug Administration (FDA), European Medicines Agency (EMA), and drug regulatory authorities (DRAs) in select developing countries to review and understand existing guidelines and explore opportunities for stimulating new thinking and approaches. Thought leaders and experts from relevant fields-contraception, prevention of STIs including HIV, product development, clinical study design, and regulatory affairs - will also help shape regulatory processes for MPTs.

\section{Critical Path for MPTs}

Product developers must negotiate scientific and technical dimensions along the critical path from innovation to commercial product. Whether working with drugs, devices, or biologics — or some combination thereof-the pathway to product development encompasses scientific, technical, programmatic, and policy dimensions. As identified by the FDA, three crucial elements of the critical path are assessing safety, demonstrating medical and or public health utility, and industrialization. Equally important elements in delivering the product to the user include:

- Ensuring regulatory approval at global, country levels

- Establishing licensing and distribution channels

- Seeding and developing markets

- Negotiating financing and procurement mechanisms

- Generating demand among potential users, providers, and policymakers

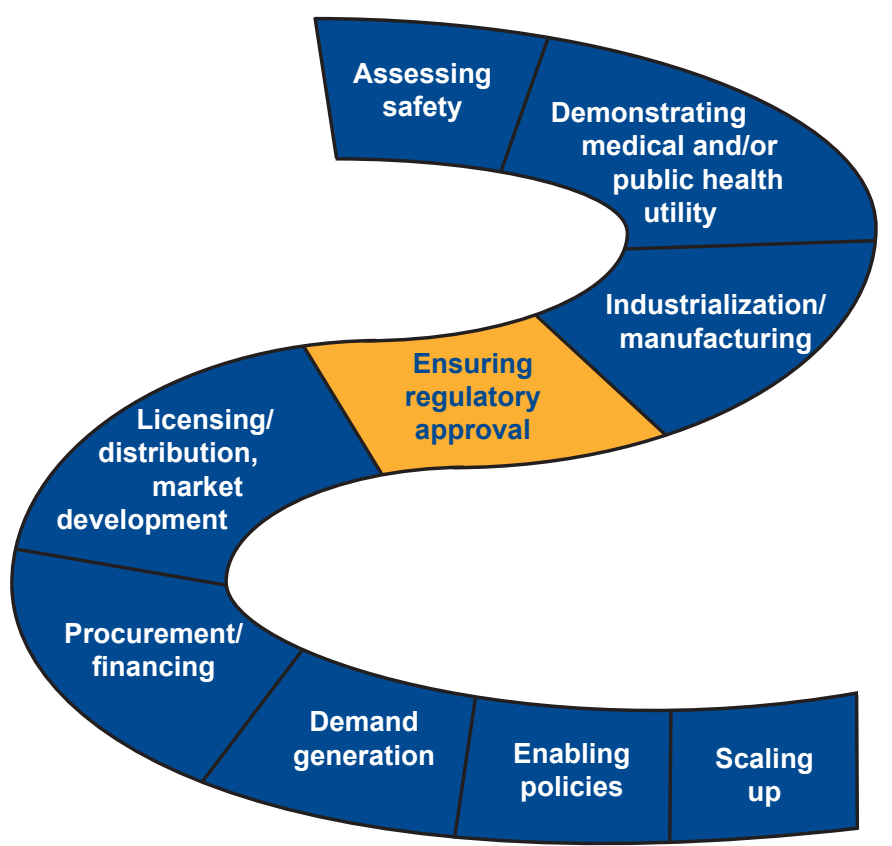

Brady, M., Critical Path Framework, @20I I Population Council.

- Developing service delivery guidelines and training

- Creating an enabling policy environment

The Council's approach to this complex and rapidly evolving arena is problem-solving and pragmatic. It draws on the Council's decades of work to understand the needs and perspectives of diverse populations in resource-poor settings, and to develop and deliver programs and products to meet these needs. Identifying clear and efficient regulatory pathways for MPTs supports a key tenet of the Council's work: ensuring that safe and effective technologies reach women and men most in need around the world.

For more information, contact Martha Brady, Project Director, at mbrady@popcouncil.org.

\section{AP Population Council}

The Population Council conducts research worldwide to improve policies, programs, and products in three areas: HIV and AIDS; poverty, gender, and youth; and reproductive health. www.popcouncil.org

Suggested citation: Brady, Martha. 20I I. "Facilitating regulatory approval of multipurpose prevention technologies for sexual and reproductive health." New York: Population Council.

Published in January 20I I. Copyright @20I I Population Council.

This document may be reproduced in whole or in part without permission of the Population Council provided full source citation is given and the reproduction is not for commercial purposes. 